\title{
The Application of the Real Options Method for the Evaluation of High-Rise Construction Projects
}

\author{
Aleksandr Izotov ${ }^{1}$, Olga Rostova ${ }^{2}$, and Alissa Dubgorn ${ }^{1, *}$ \\ ${ }^{1}$ Peter the Great St. Petersburg Polytechnic University, Institute of Industrial Economics, \\ Management and Trade, 195251 St. Petersburg, Russia
}

\begin{abstract}
The paper is devoted to the problem of evaluation of high-rise construction projects in a rapidly changing environment. The authors proposed an algorithm for constructing and embedding real options in highrise construction projects, which makes it possible to increase the flexibility of managing multi-stage projects that have the ability to adapt to changing conditions of implementation.
\end{abstract}

\section{Introduction}

The development of an investment and construction complex based on application of new technologies and equipment, the introduction of progressive forms of organization of construction production, the use of modern materials and products cannot be sufficiently effective without using the theory of construction projects investment management [1].

High-rise construction projects are subject to a number of risks, which, if implemented, can lead to significant deviations in the actual results of project implementation from the planned. The most significant are the following risks: the technologies used may not be viable due to engineering mistakes, planned technical parameters are not met, the quality of the constructed facilities does not meet the requirements of consumers, rapid and frequent innovations can lead to obsolescence of the technology even before the end of the project. The risk of incorrect choice of the project site, its inconsistency with the surrounding buildings, errors in constructive solutions, incorrect selection of materials and inaccurate definition of the layout of the facility should also be noted $[2,3]$. The end of the project may coincide with a slowdown in the development of the regional economy or unfavorable changes in market conditions, which may lead to a lack of demand for a new facility or a lower demand compared to the planned one. Features of analysis and classification of risks of the construction industry are considered in [4,5].

There is a problem that having assessed the risk of implementing a high-rise construction project as high, companies refuse to invest. However, if you take into account the possibility of making a decision on its further implementation at certain stages of the project, when analyzing the project, its investment attractiveness can significantly increase.

\footnotetext{
* Corresponding author: dubgorn@spbstu.ru
} 
Most often, the cash flow analysis method (DCF method) and the definition of its net present value (NPV) for the current period [6] are used to assess the commercial attractiveness of high-rise construction projects. But the longer the project, the more innovative it is, the more difficult it is to assess both the cash flows themselves and their possible deviations.

In various sources, it is recommended to use various modifications of the DCF method to assess project risks, in particular, analysis of possible scenarios, the Monte Carlo method, fuzzy-set theory methods, statistical methods [7,8]. But all these approaches are either too lengthy or require a very large amount of initial information. In addition, these methods do not have sufficient flexibility in a rapidly changing environment. They do not take into account the possibility to change the decision on the further implementation of the project at its certain stages. Therefore, when projects that allow step-by-step implementation or give an opportunity to exit the project before its completion are considered, it is expedient to use the real options method $[9,10]$. Unlike the cash flow method, this method evaluates not the project parameters, but the value of the investor's right to make flexible investment decisions within the project in case of changing conditions in the real estate market.

\section{Materials and Methods}

The research proposes an algorithm for constructing and building real options into high-rise projects that allow an investor, on the one hand, to protect against the consequences of unfavorable events, and on the other hand, not to miss the potential opportunities that may appear during the course of implementation.

The evaluation of investment projects using the real options method is based on the assumption that any investment opportunity for the company can be considered as an option, that is, the company has the right, and not the obligation to create or acquire assets for some time $[11,12]$.

However, if the company does not have the opportunity to implement the project step-bystep or in case of failure to leave the project before its completion, minimizing losses, then the company faces the choice of investing now or not, which does not contain real options.

The use of this estimation algorithm assumes at the first stage the evaluation of the project by applying traditional methods of investment analysis. The indicators of commercial efficiency of the project are calculated, risk analysis is carried out using the sensitivity analysis method, the scenario approach and the Monte Carlo method. In the second stage of the evaluation, the real options method is used, scenarios of variability in making investment decisions in the project implementation process are identified.

When analyzing a project, it is necessary to identify what its flexibility is and what real options can be present in it [13]. It is also necessary to assess the cost of implementing options, in which cases it is possible and what benefits it will bring.

This method is based not on the study of the most probable or averaged scenario (like DCF analysis), but on the study of project milestones in which several development options are possible. It is directed not only to detection, but also to the purposeful creation of such points. The optional characteristics are determined at the design and development stages of the project and can be used or not used, depending on the current state of the project and fluctuations in the external environment at the stages of project implementation and completion [14-15]. 


\section{Results}

For approbation of proposed method, the project of building a high-rise business center (BC) was considered.

The project implementation period is 7 years. The construction phase takes 2 years, the lease of premises is carried out within the next 5 years. At the end of the 5 th year of operation, the $\mathrm{BC}$ is being sold.

The required volume of the project financing is 28260 thousand dollars, including own investments of 10900 thousand dollars. The cost of the land plot is 1110 thousand dollars.

The length of the construction is 24 months. It is assumed that all the approvals, the development of the architectural concept, the project documentation will be completed within 6 months, and the construction itself will be completed within 1.5 years. The discount rate is $16.74 \%$.

Initially, the project was analyzed on the basis of the cash flow discounting method. The main financial indicators were obtained (for a realistic scenario):

- Discounted payback period of investments (DPBP) $(D P P)=7$ years,

- Net Present Value (NPV) $=4300$ thousand dollars,

- Internal Rate of Return (IRR) $=21.6 \%$ per annum,

- Investment profitability $(\mathrm{PI})=1.2$.

Analysis of these indicators shows that the project is acceptable for implementation:

To analyze the risks of this project, a simulation method was applied. As a result of 10,000 experiments, it was found that the probability of failure of this project is $6.5 \%$. However, the coefficients of variation of the project parameters are great. So for the NPV coefficient of variation is $65.7 \%$, which indicates a high uncertainty.

Consider the real options embedded in the project: option to delay; option to expand; option to refuse, option for stage-by-stage project implementation (stage option).

\subsection{Option to delay}

After buying a land plot, you can postpone the commencement of construction until the market conditions are favorable. In accordance with the obligations of the developer, the construction can be postponed only for 3 years. The basic asset is the current value of expected revenues from the project, the strike price is equal to the investment size.

We form the tree of possible values of the underlying asset for three years (Figure 3). The measure of uncertainty obtained by means of simulation modeling makes $17 \%$. It is assumed that during each period of time the value of the underlying asset can either increase with a coefficient of 1,185 , or decrease with a coefficient of 0.84 .

At the second stage, the option value tree is built (Figure 2). Calculations begin with the rightmost nodes. If the cost of income from the project in the node exceeds the amount of investment in the project, then at this point it is advisable to invest and get a difference between these values, otherwise it is worth refusing the project.

In the intermediate nodes the most favorable way is chosen: to execute the option immediately or delay. The valuation is performed by constructing an equivalent portfolio, which consists of a basic asset and risk-free bonds and completely repeats the yield of the option. Figure 3 shows the calculation of the equivalent portfolio parameters for the top node of the second period. 


$\longdiv { 1 \text { year } } 3$ year

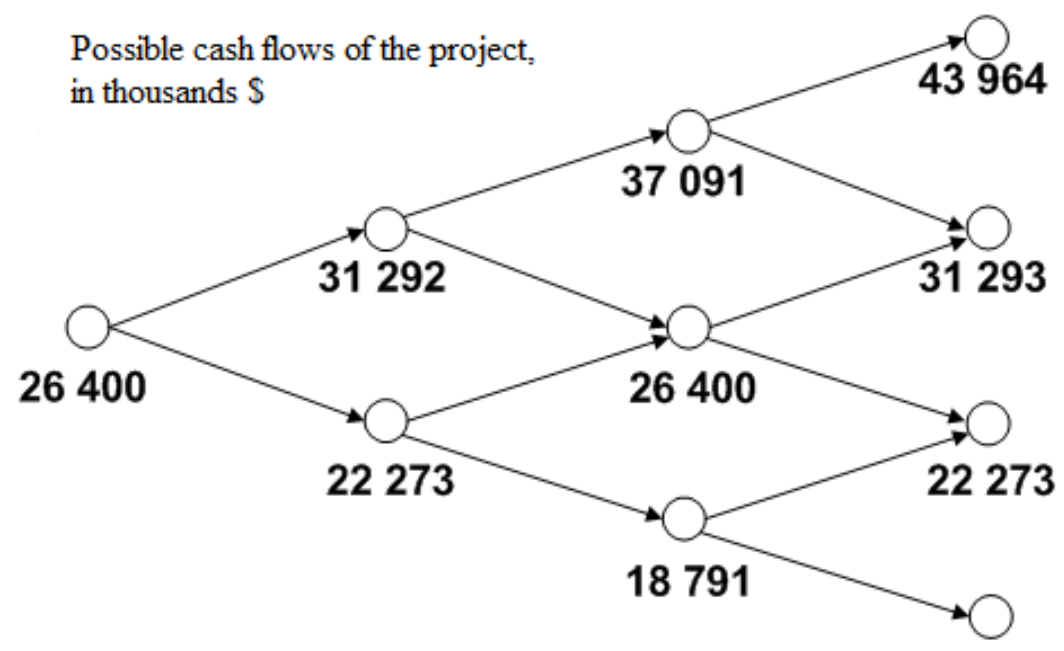

15854

Fig. 1. The tree of possible values of the basic asset.

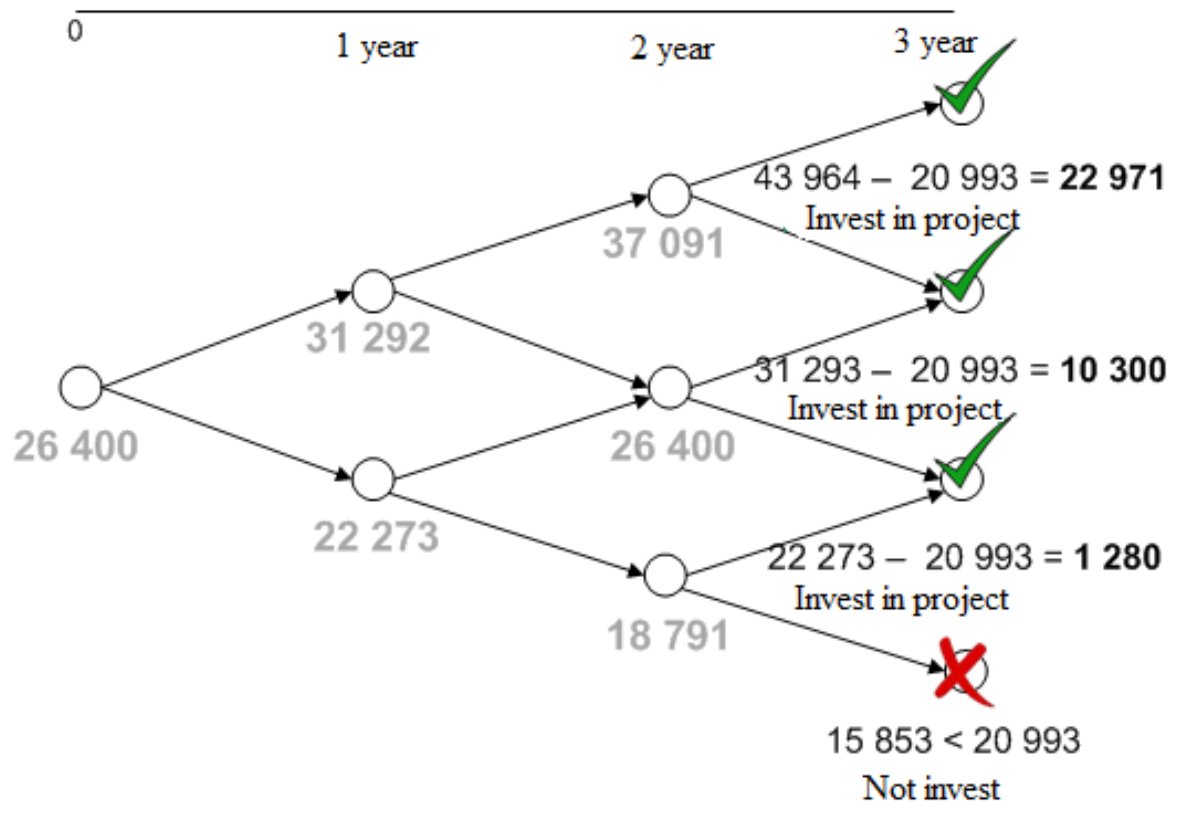

Fig. 2. The tree of option value. 


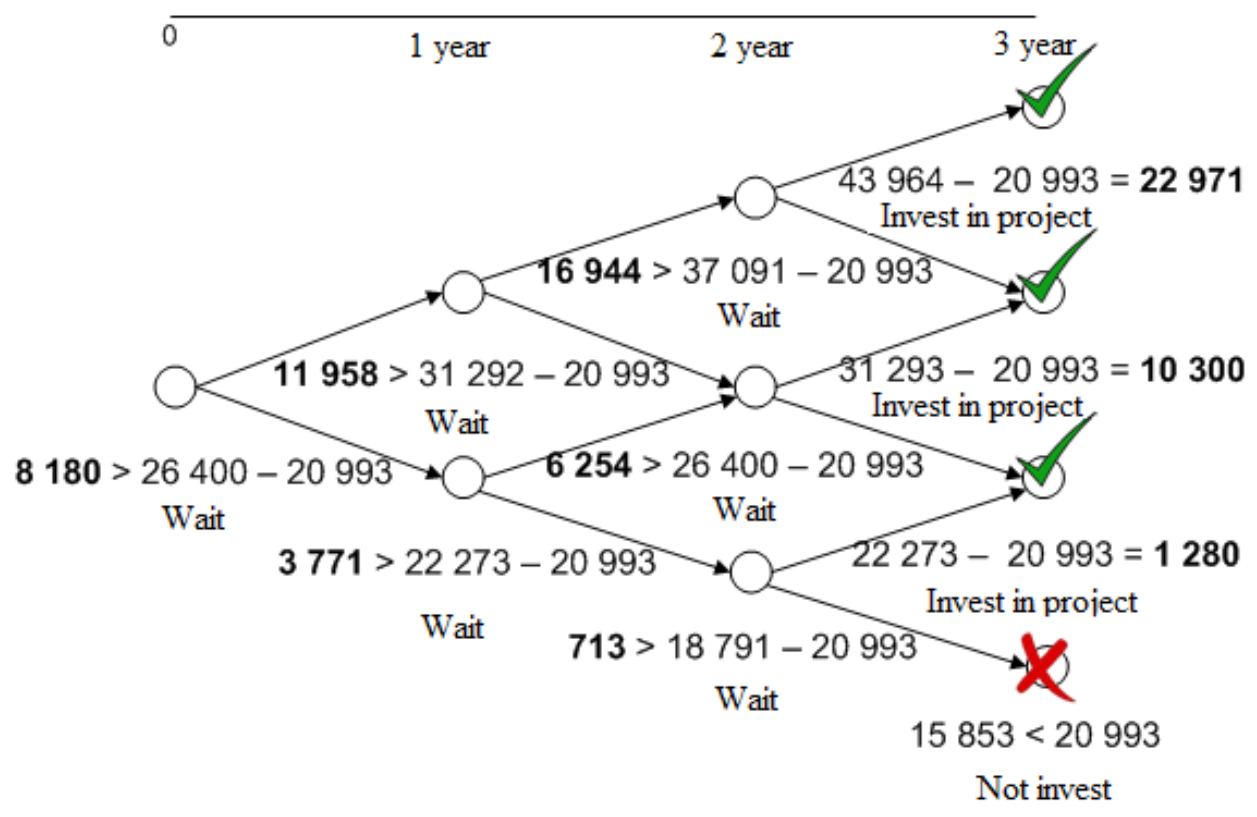

Fig. 3. The tree of option value.

Folding the model from right to left, we find the desired value - the value of the option at time t0. Taking into account the cost of acquiring a land plot, the cost of the project when choosing the option to delay will be $\$ 7$ million. The net present value has increased approximately 1.5 times.

\subsection{Option to refuse}

It is assumed that within the first two years after the start of the project, the developer can sell the site to a third party buyer with a partially constructed object. The price of sales is defined as the sum of the capital costs at the previous stages.

The project cost tree, taking into account the built-in refuse option, is shown in Figure 6. It may be profitable for a developer to leave the project following the results of the second year if the market develops according to a pessimistic scenario. This real option raises NPV by 1 million dollars. 


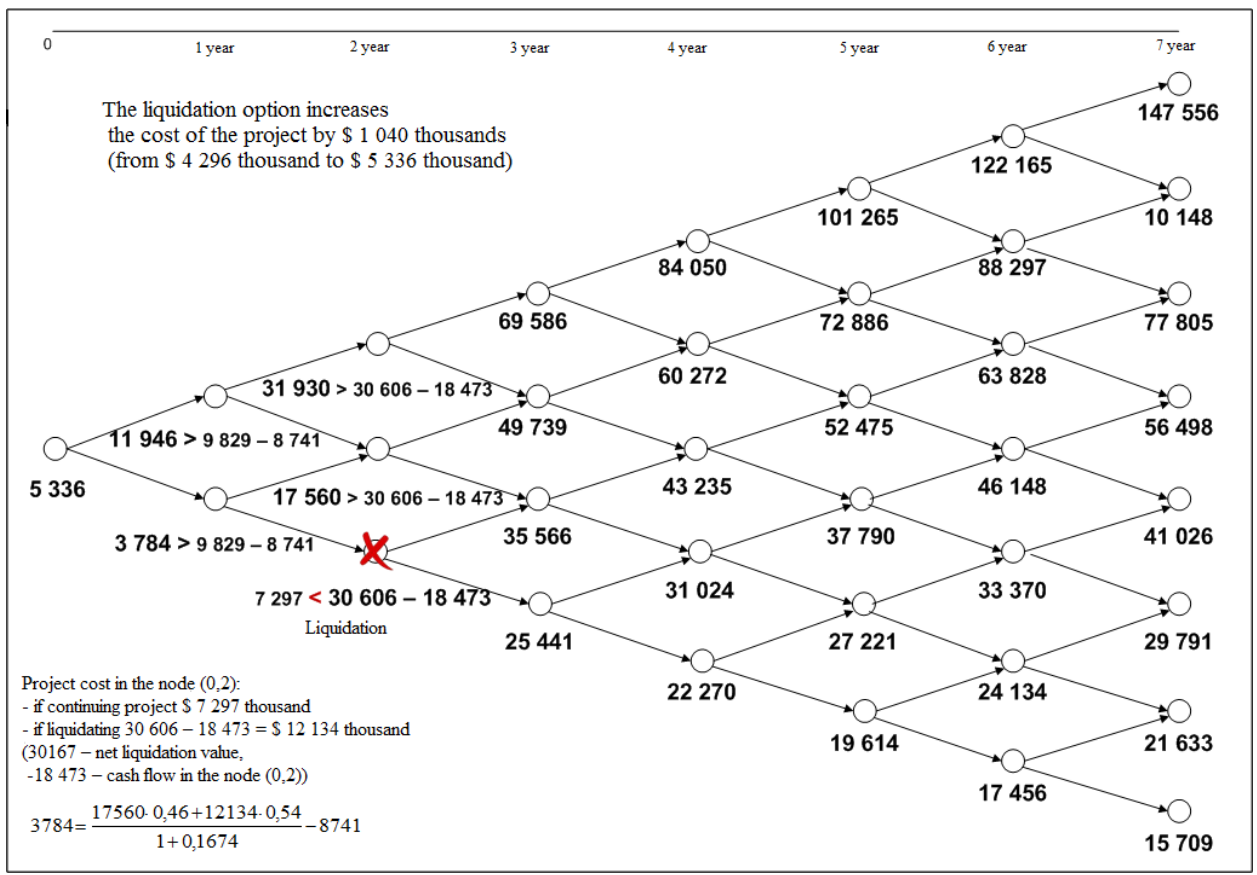

Fig. 4. Option to refuse: the tree of option value.

\subsection{Option to expand}

A real option to expand the scale of the project exists at the stage of development of project documentation. The real option to increase the office center area by $10 \%$, valid for 6 months was considered. Flexibility in this case raises the project cost by 600 thousand dollars. Figure 5 shows the decision tree for this option.

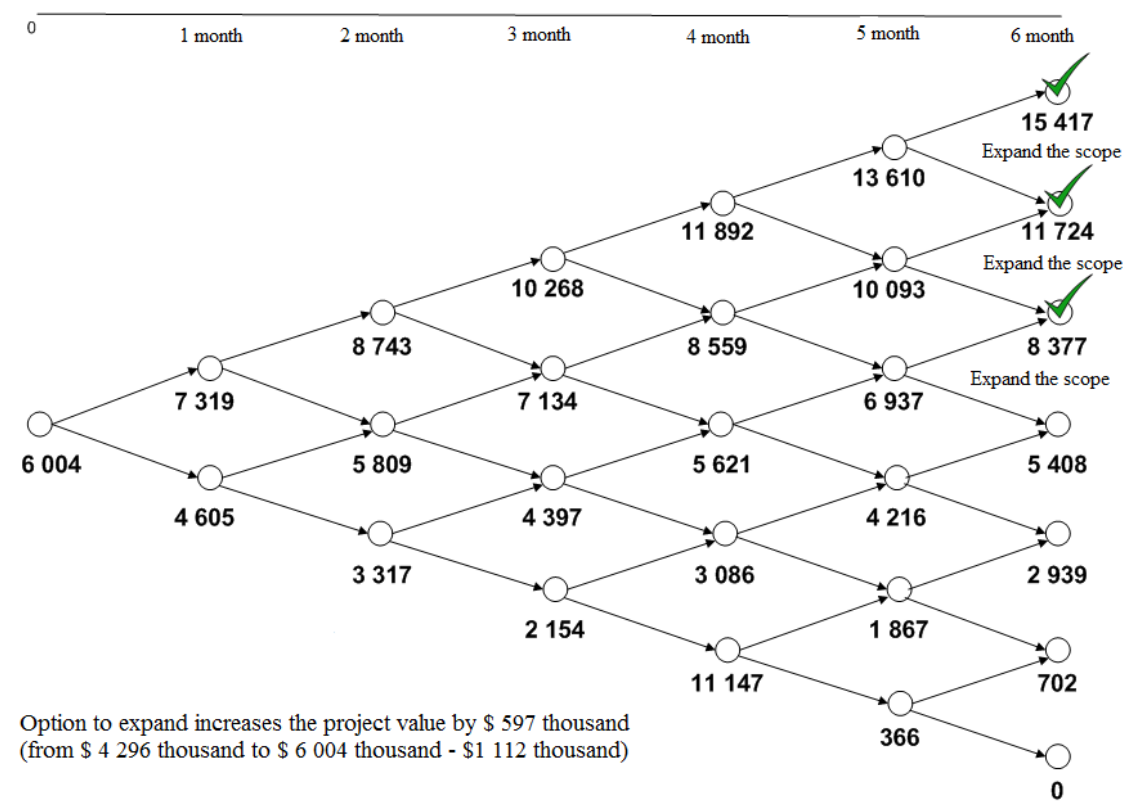

Fig. 5. Option to expand: the tree of option value. 


\subsection{Stage option}

Since the construction of a large facility at once is rather risky, the construction project can be split into two stages. This is an opportunity to gradually enter the market, as well as take into account new information in the implementation of subsequent phases of the project. The option for phased implementation raises the project cost by $\$ 2.4$ million. The decision tree of this option is shown in Figure 6.

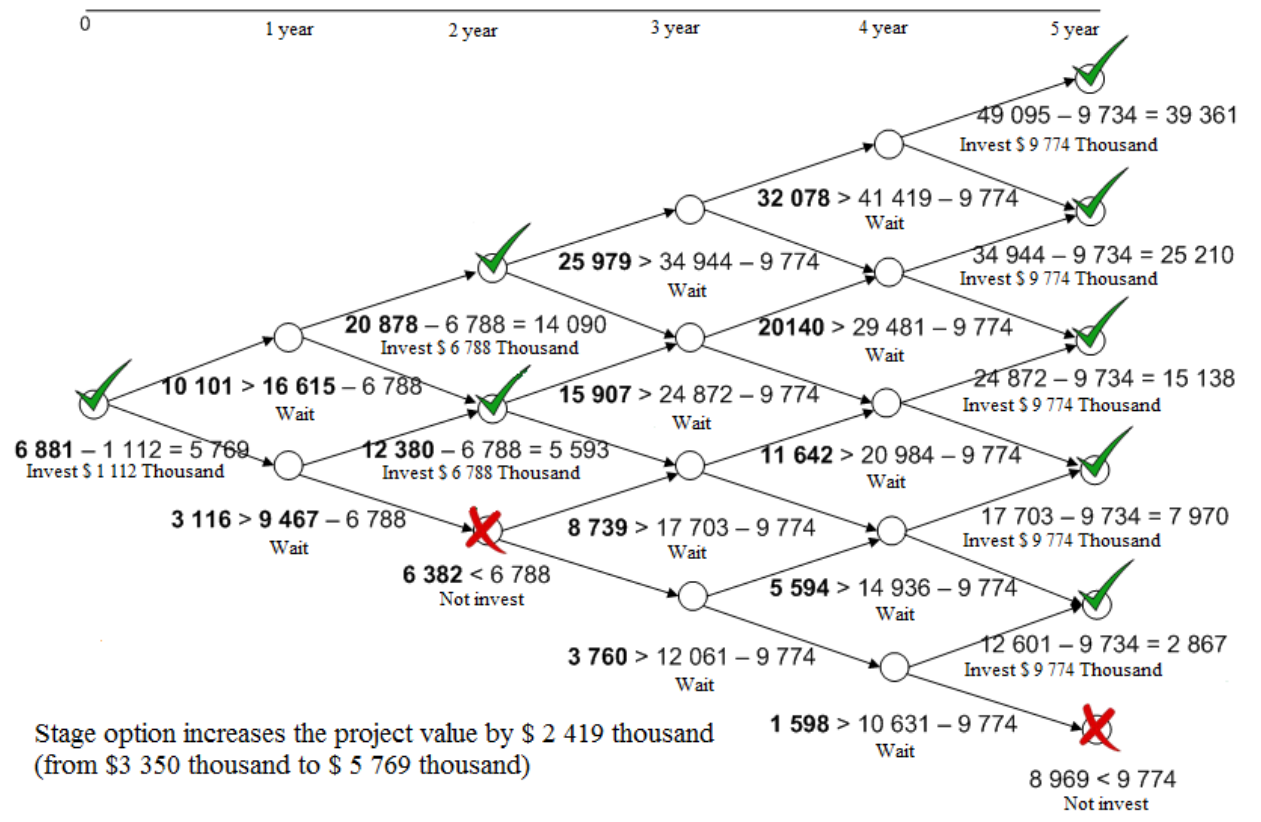

Fig. 6. Stage option: the tree of option value

The table 1 shows main characteristics of the real options discussed above.

Table 1. Summary of discussed real options.

\begin{tabular}{|c|c|c|c|c|c|}
\hline Option & Type & Basic asset & Strike price & $\begin{array}{l}\text { Option } \\
\text { duration }\end{array}$ & $\begin{array}{l}\text { Option } \\
\text { value, } \\
\text { thousand \$ }\end{array}$ \\
\hline $\begin{array}{l}\text { Stage } \\
\text { option }\end{array}$ & compound & $\begin{array}{l}\text { Cash flow of two- } \\
\text { stage project } \\
\$ 20984 \text { thousand }\end{array}$ & $\begin{array}{l}\text { The amount of investment } \\
\text { in the first stage of } \$ 6,788 \\
\text { thousand, in the second } \\
\text { stage } \$ 9734 \text { thousand. }\end{array}$ & $\begin{array}{l}2 \text { years for the } \\
\text { first stage and } \\
5 \text { years for the } \\
\text { second stage }\end{array}$ & 2419 \\
\hline $\begin{array}{l}\text { Option to } \\
\text { refuse }\end{array}$ & put & $\begin{array}{l}\text { Cash flow of project } \\
\$ 26400 \text { thousand }\end{array}$ & Project liquidation price & 2 years & 1040 \\
\hline $\begin{array}{l}\text { Option to } \\
\text { delay }\end{array}$ & call & $\begin{array}{l}\text { Cash flow of project } \\
\$ 26400 \text { thousand }\end{array}$ & $\begin{array}{l}\text { The amount of investment } \\
\text { in the project } \\
\text { (construction cost) - \$20 } \\
992 \text { thousand. }\end{array}$ & 3 years & 2773 \\
\hline $\begin{array}{l}\text { Option to } \\
\text { expand }\end{array}$ & call & 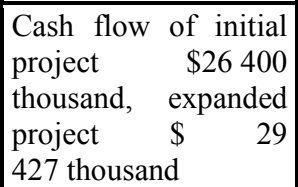 & $\begin{array}{l}\text { The cost of construction } \\
\text { of the initial object - } \$ 20 \\
992 \text { thousand and the } \\
\text { expanded project - } \$ 24 \\
085 \text { thousand. }\end{array}$ & 6 months & 597 \\
\hline
\end{tabular}




\section{Discussion}

Analysis of the project from the position of real options has allowed not only to identify additional opportunities hidden in the project, allowing the investor to feel more confident in a risky environment, but also to quantify them.

The possibility of influencing the course of the investment process has a certain value, which is taken into account when assessing the effectiveness of the project. Therefore, the proposed scheme for designing optional characteristics of an innovative project at the preinvestment stage of its implementation allows the investor to avoid underestimation of NPV cash flows in conditions of uncertainty of the external environment. The method of real options allows to include in the project a number of additional opportunities that can reduce investors' uncertainty about the future cash flow, as well as assess the contribution of these opportunities to the overall value of the project even at the stage of pre-project preparation.

It is important not only to calculate the value of the project, but also to plan for future flexible solutions in the draft. If the cash flows exceed expectations, then the project can be expanded; if there are less than expected, the project can be reduced or stopped altogether. Using the real options method allows management to focus not on absolutely accurate forecasts, but on determining alternative ways of project development, the ability to flexibly respond to changing external conditions.

\section{Conclusion}

The valuation of options provides important additional information and thus contributes to the reasonableness of the decisions made about the feasibility of implementing innovative projects, especially when projects are considered that have significant opportunities for adaptation to changing conditions, as well as multi-stage projects. The evaluation of real options should not be considered as an alternative, but as an addition to the DCF method, refining the estimates obtained by traditional methods.

\section{References}

1. D. Chubrik, Introduction of BIM: Myths and Reality, High-rise buildings, No. 4, pp. 139-147, (2014)

2. A.E. Plahin, A.Yu.Kokovihin, E.S. Ogorodnikova, S.A. Suslov, Assessment of influence of infrastructure projects on development of the territory, NGIEI bulletin, No. 11, pp. 139-147, (2017)

3. M.N. Shchukina, Modern high-rise construction, Moscow: GUP "ITC of Moscomarchitecture", 401 p., (2007)

4. T. F. Morozova, L. A. Kinayat, A. Zh. Kinayat, Assessment of risks in construction, Construction of Unique Buildings and Structures, No. 5 (10), pp. 68-76, (2013)

5. B. S. Seytzhanov, The risks of the construction industry - classification and characteristics analysis, URL: http://www.be5.biz/ekonomika1/r2011/00585.html (20.12.2017)

6. A. Kalashnikov, N. I. Vatin, Organization, management and planning in construction. Basic principles and fundamentals of organization of investment and construction projects, SPb.: Publishing house of Polytechnic University, (2011)

7. A.V. Izotov, O. V. Rostova. Development of a system of sectoral investment priorities, Proceedings of the 29th International Business Information Management Association Conference 3-4 May 2017 Vienna Austria, pp.1822-1832, (2017) 
8. S. Ptuhina, A. A. Liskov, I. A. Ptuhin, Development of total cost management in construction, Construction of unique buildings and structures, No. 5. pp. 17-20, (2012)

9. I.V. Ilyin, O.V. Rostova, Investment Management, SPb.: Publishing house of Polytechnic University, (2017)

10. T.A. Khudyakova, A.V. Shmidt, Uncertainty of External Environment during the Construction of the Controlling System of Sustainability, Proceedings of The 26th International Business Information Management Association Conference, pp. 16071611, (2015)

11. I.S. Sokolova, E.V. Gubanova, S.V. Solovyeva, The use of financial instruments in the formation of an effective securities portfolio, NGIEI bulletin, No. 9 (64), pp. 123-137, (2016)

12. L. E. Brandao, J. S. Dyer, W. J. Hahn, Using Binomial Decision Trees to Solve RealOption Valuation Problems, Decision Analysis, Volume 2, Issue 2, pp. 69-88, (2005)

13. I.V. Ilin, O.V. Kalinina, A.I. Levina, O.Yu. Iliashenko, Approach to Organizational Structure Modelling in Construction Companies, MATEC Web of Conferences. 5th International Scientific Conference on Integration, Partnership and Innovation in Construction Science and Education, IPICSE 2016, article number 05028, (2016)

14. A.R. Bril, O.V. Kalinina, I.V. Ilin, Small innovative company's valuation within venture capital financing of projects in the construction industry, MATEC Web of Conferences, Volume 106, 08010, International Science Conference SPbWOSCE-2016 "SMART City", (2017)

15. V.V. Glukhov, I.V. Ilin, Project Portfolio Structure in a Telecommunications Company, Lecture Notes in Computer Science, Volume 8638, pp. 509-518, (2014) 